Praca poglądowa/Review paper

\title{
Sztuczna inteligencja i automatyczne planowanie leczenia - o roli fizyka medycznego we współczesnej radioterapii w świetle doniesień ESTRO 2020.
}

\section{Artificial intelligence and automatic treatment planning - aspects of the role of the medical physicist in modern radiation oncology presented at the ESTRO 2020 conference.}

\section{Patrycja Borowska ${ }^{1}$}

${ }^{1}$ Zakład Radioterapii III, Wielkopolskie Centrum Onkologii, Poznań, Polska

\section{Streszczenie}

Celem niniejszej pracy jest podsumowanie doniesień na temat roli fizyka medycznego w zastosowaniu sztucznej inteligencji i automatyzacji planowania leczenia na podstawie prezentacji ustnych, wykładów oraz sympozjów przedstawionych podczas 39. konferencji Europejskiego Towarzystwa Radioterapii i Onkologii - ESTRO (ang. European SocieTy for Radiation and Oncology). Wprowadzenie nowinek technologicznych w radioterapii niesie z sobą nie tylko liczne korzyści, ale także szereg wyzwań. Współczesny fizyk medyczny stanowić musi łącznik pomiędzy specjalistami różnych dziedzin, zaangażowanymi w przygotowanie i realizację procesu leczenia pacjenta.
Abstract treatment.
Adres do korespondencji
Patrycja Borowska
Zakład Fizyki Medycznej,
Wielkopolskie Centrum Onkologii, ul. Garbary 15, 61-866 Poznań, Polska
Telefon. +48 61????????
e-mail: patrycja.borowska@wco.pl

The aim of this paper is to report the aspects of the role of the medical physicist in implementation of artificial intelligence and automatization in treatment planning presented during 39. ESTRO (European SocieTy for Radiation and Oncology) conference. Implementation of new technologies in radiotherapy not only provides many benefits, but brings certain challenges as well. There is a need for the modern medical physicist to be the link between various specialists engaged in the process of design and execution of the 
Słowa kluczowe: sztuczna inteligencja, AI, automatyczne planowanie leczenia

Keywords: artificial intelligence, AI, automatic treatment planning

\section{Wstęp}

Zastosowanie sztucznej inteligencji (ang. Artificial Intelligence, AI) i systemów automatycznego planowania leczenia w radioterapii oraz rola fizyków w bezpiecznej implementacji nowoczesnych technologii stanowiły istotną część tematów poruszonych podczas 39. konferencji ESTRO, która ze względu na wyjątkowe okoliczności spowodowane pandemią COVID-19 odbyła się online na przełomie listopada i grudnia 2020.

Tradycyjne, manualne planowanie leczenia jest procesem interaktywnym i iteracyjnym. Polega ono na dopasowywaniu parametrów w systemie planowania leczenia (ang. Treatment Planning System, TPS) aż uzyskane zostaną minimalne wymagania dla pokrycia objętości tarczowej (ang. Planning Target Volume, $P T V$ ) i dawek w narządach krytycznych (ang. Organs at Risk, OAR), a osoba planująca uzna, że uzyskała najlepszy możliwy plan leczenia. Rozwiązanie takie ma dwie zasadnicze wady - procedura jest czasochłonna, wymaga od planującego rozwiązania złożonego, wielokryteriowego problemu, którego cele niejednokrotnie wykluczają się, jest także subiektywna - jakość końcowego planu leczenia jest zależna od umiejętności i doświadczenia osoby, która go stworzyła [1].

Odpowiedzią na te problemy mogą być dostępne komercyjnie systemy automatycznego planowania leczenia.

\section{Systemy automatycznego planowania leczenia}

\section{Dostępne są trzy rodzaje systemów automatycznego planowania leczenia:}

(1) Oparte na wiedzy (ang. Knowledge-Based Planning, KBP),

(2) Oparta na protokołach automatyczna optymalizacja iteracyjna (ang. Protocol-Based Automatic Iterative Optimization, PBAIO),

(3) Optymalizacja wielokryterialna (ang. Multi-Criterial Optimization, MCO).

Istnieje możliwość wdrożenia komercyjnej aplikacji umożliwiającej automatyczne planowanie leczenia.

Systemem typu KBP jest Rapidplan (Varian Medical System, Palo Alto, CA, USA). W tego rodzaju rozwiązaniu podstawą do stworzenia nowego planu leczenia jest zgromadzona baza danych tomografii komputerowych (ang. Computed Tomography, CT) pacjentów i przygotowanych dla nich planów leczenia. Na ich podstawie system generuje modele predykcyjne dla dobrania takich ustawień TPS, które dadzą gotowy plan dla nowego pacjenta. Ponieważ nowe plany w tego rodzaju systemie są w zasadzie interpolacją między planami już istniejącymi, kluczowym dla ich jakości jest zgromadzenie bazy danych jak najlepszych planów jeszcze przed rozpoczęciem korzystania z tego rozwiązania.

Dla pozostałych dwóch typów systemów automatycznego planowania, nie istnieje zależność pomiędzy jakością planu wygenerowanego a jakością dotychczasowych planów.

Przykładem rozwiązania typu PBAIO jest Pinnacle Auto-Planning (Philips Radiation Oncology Systems, Fitchburg, WI, USA). Jego działanie opiera się na zdefiniowanych wcześniej technikach leczenia (ang. Treatment Techniques, TT). Iteracyjność tego systemu polega na tym, że nowy plan generowany jest wielokrotnie zanim uzyskany zostanie plan finalny. Określenie „protocol-based” oznacza, że kolejne iteracje polegają na dostosowywaniu parametrów optymalizacji na podstawie dawek uzyskanych w dotychczas wygenerowanych planach. TT to nic innego jak wstępnie wygenerowane przez automatyczne planowanie dla grupy pacjentów testowych parametry optymalizacji dla konkretnej lokalizacji leczenia. TT określają cele dla PTV i ograniczenia dla OAR, priorytety dla konfliktów, kryteria zgodności planu oraz sposób w jaki automatycznie wprowadzane są poprawki w kolejnych iteracjach dla uzyskania optymalnego planu. 
Ostatni rodzaj systemu automatycznego planowania - MCO - reprezentuje Erasmus iCycle. Jest to rozwiązanieopracowaneprzezzespółbadaczyzErasmus MedicalCenterw Rotterdamie, projekt sponsorowany był częściowo przez granty Elekta, Accuray i Varian. Obecnie w fazie komercjalizacji jest aplikacja oparta na tym systemie - iCycle (Elekta). Działanie systemu typu autoMCO polega na wygenerowaniu jednego planu Pareto-optymalnego, który jednocześnie jest planem klinicznie najlepszym. W tym celu system bazuje na predefiniowanych protokołach optymalnych parametrów dla danej lokalizacji leczenia (ang. wish list). Każda z „wish-list” zawiera warunki które muszą być bezwzględnie spełnione (ang. constraints) oraz te, które spełniane są w miarę możliwości (ang. objectives), bez naruszenia „constraints” i zgodnie z nadanymi im priorytetami [2].

\section{Zalety automatycznego planowania leczenia}

Wprowadzenie do użytku automatycznych systemów planowania leczenia niesie szereg korzyści:

- redukcja czasu pracy niezbędnego do wygenerowania planu leczenia [1, 2],

- może poprawić jakość planów, która nie zależy już od doświadczenia osoby je tworzącej [1,2],

- sprzyja standaryzacji - zarówno w danym ośrodku poprzez ustalenie jednolitego protokołu dla danej kliniki stosowanego dla pacjentów leczonych w danej lokalizacji, jak i pomiędzy ośrodkami stosującymi ten sam system $[1,2]$,

- personalizacja planu - redukcja czasu potrzebnego dla wygenerowania pojedynczego planu leczenia pozwala stworzyć dla pacjenta bibliotekę planów z zastosowaniem różnych technik leczenia i wybrać plan optymalny [1],

- możliwość zastosowania w dostosowaniu planu leczenia do anatomii danego dnia - dla pacjentów, u których istotny wpływ na leczenie mogą mieć na przykład różnice w wypełnieniu pęcherza, pozwala w prosty sposób wygenerować zbiór planów dla różnych stopni wypełnienia pęcherza, spośród których do realizacji danego dnia wybierany jest plan najbardziej adekwatny [1].

\section{Automatyzacja oceny planów leczenia}

Ostatnim manualnym etapem procesu planowania leczenia jest ocena gotowego planu. Niejednokrotnie trudno jednoznacznie stwierdzić, czy dany plan jest optymalny czy istnieje jeszcze możliwość udoskonalenia go, ponieważ kryteria kliniczne są zbyt ogólne. Auto-Plan quality check jest narzędziem stanowiącym próbę odpowiedzi na ten problem. W The Netherlands Cancer Institute (NKI) stosowane jest od lutego 2020 do automatycznego zatwierdzania planów leczenia dla napromieniania prostaty (z nasieniowodami lub bez) bez węzłów chłonnych do dawki całkowitej 6o Gy. System na bazie dwóch typów kryteriów: klinicznych i statystycznych (określonych na podstawie anatomii pacjenta i na bazie populacji) automatycznie zatwierdza plany leczenia, które uznaje za optymalne i wyznacza plany wymagające manualnego dopracowania. Kryteria oceny planów leczenia przez aplikację są wyznaczone na podstawie grupy klinicznie zaakceptowanych planów, jest to więc model typu knowledge-based. Do nauki modelu zastosowano 42 plany leczenia, przetestowano go wstępnie na grupie kolejnych 10 planów, a następnie zwalidowano z zastosowaniem 48 planów leczenia. W teście klinicznym dla 35 wygenerowanych automatycznie przy pomocy Pinnacle Auto Planning (Phillips) planów leczenia porównano ocenę tych planów przez model i manualną ocenę przez doświadczonego fizyka. Oceniono na tej podstawie czułość (wyniosła 1) oraz specyficzność (wyn. o,83) modelu. W badaniu wykazano, że wszystkie plany zaaprobowane przez system były klinicznie akceptowalne - zastosowanie narzędzia nie spowodowało pominięcia żadnego planu wymagającego dodatkowej optymalizacji. Jednocześnie należy zaznaczyć, że dalszej manualnej kontroli wymagało 48\% sprawdzonych automatycznie planów. W przypadku 37\% planów udało się, po dodatkowej ręcznej optymalizacji, osiągnąć lepszy plan finalny, natomiast w 11\% przypadków to kryteria oceny okazały się być zbyt surowe (planu nie dało się udoskonalić). Zastosowanie narzędzia Auto-plan quality check sprawiło, że w NKI planowanie radioterapii prostaty odbywa się w najprostszych przypadkach w pełni automatycznie od etapu konturowania począwszy na akceptacji finalnego planu leczenia skończywszy [3]. Takie rewolucyjne podejście pozwala fizykom pracującym w ośrodku przeznaczyć zaoszczędzony czas na inne zadania. 


\section{Automatyczne planowanie nie eliminuje człowieka z procesu przygotowania planu}

Zastosowanie programów umożliwiających automatyczne planowanie leczenia nie oznacza, że fizyk w zakładzie radioterapii staje się zbędny, jego rola ulega jedynie modyfikacji. Ograniczenie zaangażowania koniecznego do generacji planu leczenia pozwala na redystrybucję czasu pracy na inne zadania - konfigurację i walidację systemu, a następnie stałą kontrolę jakości uaktualnień i monitorowanie działania aplikacji [1, 2], stałe modyfikowanie konfiguracji pod wpływem nowych badań klinicznych/nowych podejść lekarzy [2], badanie możliwości tworzenia i generowanie nowych konfiguracji [2]. Planowanie automatyczne nie znajduje zastosowania w sytuacjach wyjątkowych - aby z niego skorzystać trzeba dysponować bazą analogicznych przypadków lub w innych systemach wiedzieć do jakiego efektu końcowego się dąży - w takich scenariuszach system nie jest (jeszcze) w stanie zastąpić doświadczonego fizyka [1,2]. Proces oceny planu jest również trudny do zautomatyzowania, choć podejmowane są próby wprowadzenia tego typu rozwiązań [3], ponieważ wybór planu optymalnego jest subiektywny i zależy od własnych preferencji fizyka/lekarza. Ponieważ brak jest konsensusu co do sposobu oceny planów, pojawia się również potrzeba manualnego wykończenia przez fizyka planu wygenerowanego automatycznie aby spełniał wymagania danego lekarza prowadzącego $[1,2]$. Można w takich przypadkach rozważać, czy zawiodła automatyzacja czy też brak jest dostatecznej standaryzacji w klinice [1].

\section{Sztuczna inteligencja w radioterapii to nie tylko planowanie automatyczne}

Możliwości zastosowania sztucznej inteligencji w radioterapii jest wiele:

- autokonturowanie PTV i OAR,

- planowanie automatyczne,

- przewidywanie odpowiedzi na dawkę (modele przewidujące prawdopodobieństwo wystąpienia komplikacji dla tkanek zdrowych (ang. Normal Tissue Complication Probability, NTCP), przeżycie, kontrola lokalna, odległe przerzuty),

- kontrola jakości (QA) - wykrywanie błędów w planowaniu,

- konwersja tomografii stożkowej CBCT (ang. Cone Beam Computed Tomography) na CT do planowania leczenia,

- generacja syntetycznych CT z obrazowania rezonansu magnetycznego MRI (ang. Magnetic Resonance Imaging),

- fuzja krzywoliniowa,

- śledzenie ruchów guza na obrazach $2 \mathrm{DkV}$,

- klasyfikacja tkanek w celu dokładnego obliczenia dawki w protonoterapii [4].

Implementacja kliniczna AI powinna być odpowiedzią na realny problem. Obecnie często schemat jest odwrócony:

natłok dostępnych danych $\rightarrow$ wymyślony na ich podstawie problem $\rightarrow$ rozwiązanie.

Rolą fizyka powinno być wyróżnienie istniejących problemów i zapewnienie specjalistom od AI i danologii (ang. data science) dostępu do odpowiedniej jakości danych, a po uzyskaniu od nich rozwiązania - objaśnienie technologii przyszłym użytkownikom (np. lekarzom), tak aby schemat wdrożenia AI wyglądał następująco:

$$
\text { problem } \rightarrow \text { dane } \rightarrow \text { rozwiązanie [4]. }
$$

Z perspektywy specjalistów od AI - narzędzia już istnieją, sukces ich zastosowania w radioterapii zależy jednak od jakości danych, których dostarczenie i interpretacja musi pochodzić od specjalistów w dziedzinie (fizyków). Historycznie rola fizyków sprowadzała się w dużej mierze do rozwoju technologii. Obecnie istnieje konieczność lepszego zrozumienia radiobiologii i modelowania. Wyzwania współczesnej radioterapii sprawiają, że konieczny jest balans pomiędzy radiobiologią, doświadczeniem klinicznym, rozwojem technologii i zrozumieniem interakcji promieniowania z organizmem. Fizycy muszą się w związku z tym otworzyć na interdyscyplinarność. Kluczem do sukcesu współczesnej radioterapii jest współpraca 
specjalistów wielu dziedzin: onkologów, lekarzy innych specjalności, specjalistów od obrazowania, fizyków medycznych, biofizyków, inżynierów, danologów (ang. data scientists), i in. To fizycy mogą i powinni stanowić łącznik pomiędzy specjalistami stanowiącymi ogniwa tego interdyscyplinarnego łańcucha [5].

Warto jedocześnie pamiętać, że nie wszyscy fizycy będą uczestniczyć w rozwoju nowych technologii. Większość z nich będzie po prostu korzystać z nich jako kolejnego narzędzia pracy, dlatego też należy w szkoleniu fizyków położyć nacisk na wykorzystanie AI w radioterapii [4].

\section{Wprowadzenie narzędzia AI do użytku klinicznego - przykład}

Najpopularniejszym zastosowaniem sztucznej inteligencji w praktyce klinicznej jest narzędzie autosegmentacji. Jak wygląda wprowadzenie nowej technologii do użytku? Proces składa się z trzech głównych etapów (Tab.1).

Tab. 1. Etapy wprowadzenia narzędzia AI do użytku klinicznego

\begin{tabular}{|c|c|}
\hline 1. $\begin{array}{c}\text { Zbieranie danych i testowanie modelu } \\
\text { (ang. comissioning) }\end{array}$ & Specyficzne dla AI (ang. AI-specific) \\
\hline $\begin{array}{c}\text { Implementacja (używanie technologii } \\
\text { méwnolegle z dotychczas stosowanymi } \\
\text { metodami, czas szkolenia personelu) }\end{array}$ & \\
\hline 3. Rutynowe zastosowanie i QA & $\begin{array}{c}\text { Niekoniecznie specyficzne dla AI - w przypadku } \\
\text { konturowania ocena jakości konturów nie zależy od } \\
\text { ich pochodzenia }\end{array}$ \\
\hline
\end{tabular}

Comissioning - etap rozwoju technologii - jego przebieg zależy od wielkości i zasobów jakimi dysponuje ośrodek. Istnieją trzy możliwości pozyskania modelu:

- zakup gotowego rozwiązania - dobre dla małych ośrodków niedysponujących bogatymi zasobami danych treningowych, nie daje jednak żadnej kontroli nad otrzymanym modelem,

- współpraca z producentem - dostarczenie przez ośrodek danych do szkolenia modelu, które przeprowadza producent, daje pewien poziom kontroli nad modelem (jakie dane posłużyły trenowaniu),

- samodzielne przygotowanie i trenowanie modelu (ang. in-house training) z zastosowaniem własnych danych, daje pełną kontrolę nad modelem, cykl szkolenia uwzględnia własne poprawki względem uzyskanych efektów, ale wymaga dysponowania bardzo dużym zasobem danych treningowych.

W przypadku zakupu gotowego modelu należy kierować się jego zastosowalnością w warunkach własnego ośrodka i być świadomym ograniczeń modelu. Gotowy model należy po zakupie ocenić przy użyciu własnych danych testowych. Uzyskane wyniki powinny być zbliżone do danych z raportu walidacyjnego załączonego przez producenta. W przeciwnym wypadku należy uznać, że zakupiony model nie jest stosowalny w warunkach danego ośrodka.

Etap implementacji powinien polegać na uruchomieniu modelu równolegle z obecnie stosowanym protokołem i ocenie działania modelu na bieżąco oraz wyłapywaniu błędów. Konieczna jest ocena ryzyka odpowiedź na pytania: co jeśli model zawiedzie? Co jeśli model stale popełnia niewielkie błędy (ang. Failure Mode Effect Analysis, FMEA). Na tym etapie odbywa się szkolenie użytkowników i tzw. testy „end to end” - sprawdzenie przez rzeczywistych użytkowników wszystkich etapów zastosowania modelu. Tworzone są podstawy kontroli „rozsądności efektu” - ocena czy uzyskany kontur zawiera się w ramach rozkładu konturów, a jeśli nie - oznaczenie go do kontroli szczegółowej. Wszelkie nieprawidłowe wyniki autosegmentacji powinny 
być archiwizowane w celu zidentyfikowania schematów, w których dany model zawodzi - są to istotne dane do re-trainingu modelu. Na etapie implementacji mierzone mogą być też poboczne parametry takie jak czas zaoszczędzony dzięki zastosowaniu modelu czy zadowolenie lekarzy z uzyskanych automatycznie konturów.

Ostatni etap, rutynowego używania modelu, wymaga opracowania strategii określającej czynności wykonywane w ramach kontroli jakości (ang. Quality Management Plan, QMP), sposobu archiwizowania wyników kontroli oraz postępowania w sytuacji wykrycia problemów w działaniu modelu. Kontrola jakości powinna być dwutorowa - dotyczyć pacjenta (każdorazowa ocena ręczna konturów wygenerowanych przez model, może być porównanie z innym, niezależnym sposobem segmentacji) oraz dotyczyć modelu (zarówno regularna, podczas rutynowego użytkowania, jak i po każdej wprowadzonej zmianie) [6]. Na każdym etapie wdrożenia technologii do użytku klinicznego niezbędne jest, jak widać w powyższym przykładzie, zaangażowanie człowieka. Rola ta nie sprowadza się tylko do bycia użytkownikiem technologii, ale przede wszystkim do stałego monitorowania jej funkcjonowania ze zrozumieniem zarówno aspektów technicznych jak i klinicznych. Jest to zadanie, jakie we współczesnej radioterapii powinien wypełniać fizyk medyczny.

\section{Podsumowanie}

Dostęp do nowoczesnych technologii zwiększa się z każdym rokiem. Automatyzacja i zastosowania sztucznej inteligencji mogą w znaczący sposób usprawnić pracę w ośrodku radioterapii. Kluczowym jest jednak, by narzędzia te wprowadzane były w sposób odpowiedzialny, ze zrozumieniem zarówno możliwości jakie dają, ale także ich ograniczeń. Współczesna radioterapia wymaga od osób zaangażowanych w jej realizację współpracy na niespotykaną dotąd skalę ze specjalistami różnych dziedzin nauki i techniki. Pozwoli to na zastosowanie wiedzy zgromadzonej na bazie wieloletnich doświadczeń i ogromnej ilości danych pochodzących od populacji do stworzenia spersonalizowanego leczenia dla indywidualnego pacjenta, kierowanego nie tylko skutecznością zwalczenia nowotworu, ale też oceną jakości życia.

\section{Bibliografia}

[1] L. Rossi, Where can automation help or cannot help the medical physicist, materiały zjazdowe konferencji ESTRO 39, online congress, 28.11-01.12.2020;

[2] B. Heijmen, Do's and dont's in automated treatment planning - optimising conditions and expectations, materiały zjazdowe konferencji ESTRO 39, online congress, 28.11-01.12.2020;

[3] K. Kiers, Artificial intelligence and automation: Treatment planning without user interaction - automatic plan approval of prostate auto-plans, materiały zjazdowe konferencji ESTRO 39, online congress, 28.1101.12.2020;

[4] W. Van Eempt, ESTRO-AAPM: The future of Medical Physics in Radiation Oncology: Medical physicists will drive the development and implementation of artificial intelligence in Radiation Oncology, materiały zjazdowe konferencji ESTRO 39, online congress, 28.11-01.12.2020;

[5] C. Clark, ESTRO-AAPM: The future of Medical Physics in Radiation Oncology: Medical physicists will be leaders in the changing world of radiation oncology, materiały zjazdowe konferencji ESTRO 39, online congress, 28.11-01.12.2020;

[6] A. Green, Validation and comissioning of AI contouring tools, materiały zjazdowe konferencji ESTRO 39, online congress, 28.11-01.12.2020; 